\title{
PROBLEMS AT A HOSPITAL CONCERNING COVID-19 PANDEMIC
}

\author{
Marselli Widya Lestari'1,2), Dewi Puspitosari H.D.2), Yohana2) \\ 1)Public Health and Prevention Medicine, Medical Faculty, \\ Universitas Nahdlatul Ulama Surabaya \\ 2)Master of Public Health Program, Universitas Diponegoro
}

\begin{abstract}
Background: Many hospitals are challenged with various problems regarding infrastructure and management in providing services during COVID-19 pandemic. Effective hospital management strategy plays an important role in confronting COVID-19. This study aimed to determine the problems faced by a hospital in the time of COVID-19.

Subjects and Method: This was a qualitative study conducted at second-line COVID-19 referral hospital, Central Java from May to July 2020. Several health professionals and staff were selected as informants of the study. The data were collected by in-depth interview and document review. The data were analyzed using urgency, seriousness, and growth (USG) method to determine the priority of the problems. Root cause of the problems was analyzed with the aspects of man, method, and material using fishbone diagram.

Results: The priority problem in the hospital under study was some of the staff infected with COVID-19. The possible root causes were (1) man: staff behaviors; (2) method: loss to followup patients to uptake screening and lack of personal protective equipment (PPE) doffing procedure; and (3) material: lack of disinfectant chambers.

Conclusion: Some of the staff infected with COVID-19 is the main problem affecting the hospital under study. Comprehensive and responsiveness of hospital strategic management in line with WHO and CDC guidelines are required to contain the disease transmission.
\end{abstract}

Keywords: hospital problems, COVID-19, strategic management

\section{Correspondence:}

Marselli Widya Lestari. Universitas Nahdlatul Ulama Surabaya. Jl. Raya Jemursari No. 57, Surabaya, East Java, 60237. Email: marselliwidya@gmail.com. Mobile: +6281703341579.

The $7^{\text {th }}$ International Conference on Public Health Solo, Indonesia, November 18-19, 2020 | 343 https://doi.org/10.26911/the7thicph.04.28 